\title{
Kinematics and Microphysics of Convection in the Outer Rainband of Typhoon Nida (2016) Revealed by Polarimetric Radar
}

\author{
Dan Wu, ${ }^{\mathrm{a}, \mathrm{b}}$ Kun ZhaO, ${ }^{\mathrm{a}}$ Matthew R. Kumjian, ${ }^{\mathrm{c}}$ Xiaomin Chen, ${ }^{\mathrm{a}}$ HaO Huang, ${ }^{\mathrm{a}}$ Minguun Wang, ${ }^{\mathrm{a}}$ \\ ANTHONY C. DidLAKE JR., ${ }^{\mathrm{c}}$ YiHONG DUAN, ${ }^{\mathrm{d}}$ AND FUQING ZHANG ${ }^{\mathrm{c}}$ \\ ${ }^{a}$ Key Laboratory of Mesoscale Severe Weather/MOE, and School of Atmospheric Sciences, Nanjing University, \\ Nanjing, and State Key Laboratory of Severe Weather, and Joint Center for Atmospheric Radar Research, \\ China Meteorological Administration/Nanjing University, Beijing, China \\ ${ }^{\mathrm{b}}$ Shanghai Typhoon Institute, Shanghai, China \\ ${ }^{\mathrm{c}}$ Department of Meteorology and Atmospheric Science, The Pennsylvania State University, University Park, Pennsylvania \\ ${ }^{\mathrm{d}}$ State Key Laboratory of Severe Weather, Chinese Academy of Meteorological Sciences, China Meteorological \\ Administration, Beijing, China
}

(Manuscript received 31 October 2017, in final form 9 May 2018)

\section{ABSTRACT}

\begin{abstract}
This study analyzes the microphysics of convective cells in an outer rainband of Typhoon Nida (2016) using data collected by a newly upgraded operational polarimetric radar in China. The life cycle of these convective cells is divided into three stages: developing, mature, and decaying according to the intensity of the corresponding updraft. Composite analysis shows that deep columns of $Z_{\mathrm{DR}}$ and $K_{\mathrm{DP}}$ collocate well with the enhanced updraft as the cells develop to their mature stage. A layered microphysical structure is observed in the ice region with riming near the $-5^{\circ} \mathrm{C}$ level within the updraft, aggregation around the $-15^{\circ} \mathrm{C}$ level, and deposition anywhere above the $0^{\circ} \mathrm{C}$ level. These ice-phase microphysical processes are important pathways of particle growth in the outer rainbands. In particular, riming contributes significantly to surface heavy rainfall. These contrast to previously documented inner rainbands, where warm-rain processes are the predominant pathway of particle growth.
\end{abstract}

\section{Introduction}

Tropical cyclone (TC) rainbands are important to study, as they can affect the structure and intensity of TCs (Barnes et al. 1983; Willoughby 1990; Wang 2009), and also directly impact the surface precipitation. TC rainbands (TCRs) are typically organized in spiral band shapes characterized by both convective and extensive stratiform precipitation outside the eyewall (Wexler 1947; Senn and Hiser 1959; Houze 2010). Generally, two types of TCRs are defined based on their positions and movement relative to the storm center: inner and outer rainbands. While inner rainbands are typically located near the eyewall, outer rainbands usually develop farther outside the eyewall, $\geq 150 \mathrm{~km}$ from the center (Willoughby et al. 1984; Wang 2002; Skwira et al. 2005).

In the past few decades, numerous studies have attempted to document the convective and mesoscale structures of TCRs with advanced aircraft instruments

Corresponding author: Dr. Kun Zhao, zhaokun@nju.edu.cn
(Barnes and Stossmeister 1986; Powell 1990a,b; Hence and Houze 2008; Didlake and Houze 2013a,b); however, most focused on inner rainbands. As mentioned in the review of Houze (2010), the environment at the outer periphery of the TC tends to have higher CAPE than the inner regions, which may lead to the observed different features of the outer rainbands. This hypothesis is supported by some observational and modeling studies in recent years (Yu and Tsai 2013; Moon and Nolan 2015). By examining the wind structure retrieved from groundbased radars, Yu and Tsai (2013) documented the kinematic and precipitation structure of outer rainbands: they exhibited a more convective nature, and their vertical wind structure included deep band-relative inflow, a rearward tilt of the updraft, and band-relative rear-tofront flow at low levels. They concluded that the airflow patterns of the outer rainband were similar to those of the convective region of squall lines. Recent numerical simulation studies also reported similar features of the outer rainbands in their real-case simulations (Akter and Tsuboki 2012; Moon and Nolan 2015). 
Aside from the mesoscale kinematic structure and associated dynamic processes within outer rainbands, few studies have ever discussed their microphysics. However, microphysical processes in the outer rainbands are important given their strong impact on TC structure, intensity change, and precipitation variation through complex interactions with the storm dynamics (McCaul 1991; McFarquhar et al. 2006; Fovell and Su 2007; Fovell et al. 2009). Recent studies also pointed to the essential role of the outer rainband in the initiation of tropical cyclone eyewall replacement cycles (Fang and Zhang 2012; Rozoff et al. 2012; Sun et al. 2013; Zhang et al. 2017). Although aircraft in situ observations are able to shed some light onto cloud microphysics in TCRs along the flight track (Black and Hallett 1986; Marks and Houze 1987; Black 1990; Black et al. 1994; Black and Hallett 1999), they cannot reveal the threedimensional distribution of hydrometeor type and size (Houze 2010).

In recent years, a more advanced and powerful toolpolarimetric radar-has been employed to provide insight into the microphysics in precipitation systems. Polarimetric radar can provide detailed information of the size, shape, and orientation of the particles within a radar sampling volume, which can help us infer the most likely ongoing microphysical processes. Such analyses have been applied to different tropical precipitation systems, including MJO convection (Rowe and Houze 2014), and TC convection (May et al. 2008; Wang et al. 2016; Didlake and Kumjian 2017). For example, May et al. (2008) described the microphysical structure in the eyewall of Tropical Cyclone Ingrid (2005) with polarimetric radar observations for the first time, and their results revealed that the retrieved hydrometeor types are consistent with the aircraft observations. Didlake and Kumjian (2017) related the microphysics of the precipitation with the overall TC dynamics and demonstrated that the ice-phase microphysical processes above the melting level vary significantly across the storm. Wang et al. (2016) examined the microphysical and kinematic characteristics of an inner rainband in Typhoon Matmo (2014) that moved far inland. These studies demonstrate that polarimetric radar observations and retrievals can be used to promote our understandings of the microphysics of TC precipitation. Although previous studies have attempted to document the precipitation microphysics in TCs, the microphysical structure in convective scale and the microphysical processes contributing to the heavy precipitation in the TC outer rainband are not fully understood.

Typhoon Nida was the fourth tropical cyclone that developed in the western North Pacific in 2016. Before it made landfall in south China, an intense outer rainband with a large number of convective cells passed near Guangzhou city at around 0900 UTC 1 August, bringing heavy precipitation (3-h accumulated rainfall $>50 \mathrm{~mm}$ ). This outer rainband (Fig. 1) was located at a radial distance of $\sim 250 \mathrm{~km}$ from the TC center and propagated southwestward.

In this study, for the first time, we document the detailed kinematic structure and microphysics associated with convective cells in a TC outer rainband, as well as their evolution during the convective life cycle. Our goal is to explore the potential microphysical processes in the outer rainband responsible for the observed heavy precipitation.

\section{Data and methods}

The primary data for the investigation of the outer rainband are collected by two S-band operational Doppler radars located at Shenzhen and Guangzhou, China, respectively (Fig. 1). The Guangzhou radar (GZRD) was recently upgraded to have polarimetric capabilities. The composite equivalent reflectivity factor at horizontal polarization $Z_{\mathrm{H}}$, the differential reflectivity $Z_{\mathrm{DR}}$, and the specific differential phase $K_{\mathrm{DP}}$ are used to examine the microphysical characteristics of the rainband. The data with correlation coefficient $\rho_{\mathrm{HV}}$ below 0.85 are discarded to remove nonmeteorological echoes. The quality control procedures applied to the data follow those in Huang et al. (2017). After quality control, the radar data are interpolated onto a Cartesian grid with $1.0-\mathrm{km}$ horizontal and $0.5-\mathrm{km}$ vertical spacing using the National Center for Atmospheric Research (NCAR) REORDER software (Oye et al. 1995). The lowest grid altitude is $0.5 \mathrm{~km}$. Dual-Doppler synthesis (Ray et al. 1978) is then applied to retrieve the three-dimensional wind field in the rainband. The two gray circles in Fig. 1 indicate the synthesis domain and the retrieved wind field extends to $15 \mathrm{~km}$ in altitude. To reduce the uncertainties and errors in the dual-Doppler-derived winds, data with cross-beam angles $<30^{\circ}$ are excluded (Doviak and Zrnić 1993).

The fuzzy-logic polarimetric radar hydrometeor identification algorithm (HID) developed by Dolan et al. (2013) is employed to estimate the particle types present in the rainband, based on the polarimetric variables collected by Guangzhou radar. In this algorithm, seven ice-phased hydrometeor types are identified, including ice crystals, aggregates, wet snow, high-density graupel, low-density graupel, hail, and vertically aligned ice. The estimated particle types can be used to infer the underlying microphysical processes. The seven types of ice-phased hydrometeors in the Dolan et al. (2013) HID algorithm used herein can reflect four types of ice 


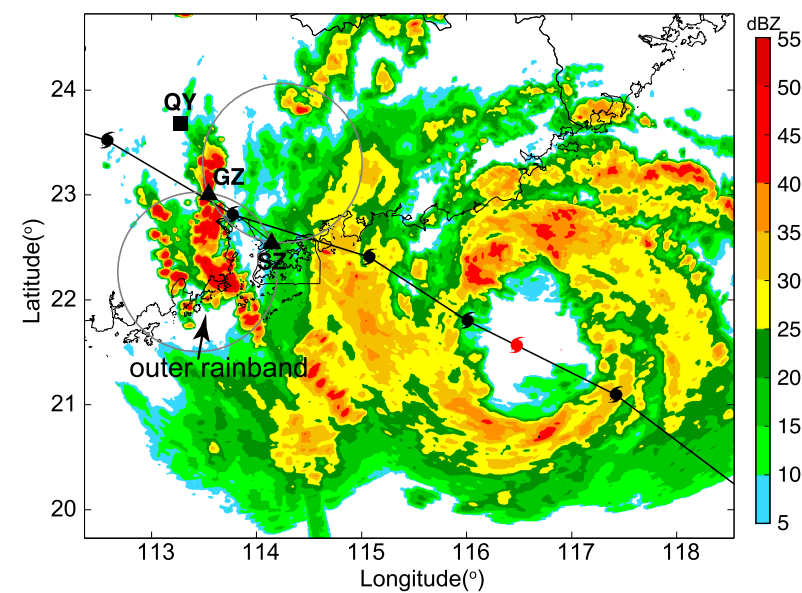

FIG. 1. The outer rainband of Typhoon Nida (2016) developing in the dual-Doppler synthesis domain (gray circles) at 1000 UTC 1 Aug. The 6-hourly track of Typhoon Nida is marked by the hurricane symbols with the red one denoting the TC center at 1000 UTC 1 Aug. Locations of the two operational Doppler radars (GZ and SZ) are marked by the black triangles. The sounding station at Qingyuan (QY) is marked by the black square.

microphysical processes: deposition, aggregation, riming, and melting. The "ice crystals" category refers to pristine ice particles that grow predominantly via vapor deposition. "Vertically aligned ice" refers to these same crystals that are reoriented by strong electric fields in the storm (e.g., Ryzhkov and Zrnić 2007; Hubbert et al. 2014). The "aggregates" suggest the aggregation of pristine ice crystals into larger, tumbling conglomerates. The "high- and low-density graupel" and "hail" categories imply riming. These three processes are the main ice-phased particle growth processes. Finally, "wet snow" usually is an indication of melting in the case of a well-defined melting layer brightband signature.

A rawinsonde released at Qingyuan at 0600 UTC 1 August provides the environmental conditions prior to the rainband formation in the analysis domain (Fig. 2). The thermodynamic characteristics prior to rainband formation were unsaturated throughout the troposphere, especially at midlevels. The CAPE was about $3507 \mathrm{~J} \mathrm{~kg}^{-1}$, which is comparable to the observed CAPE value of a typical midlatitude continental squallline environments (e.g., Bluestein and Jain 1985; Wyss and Emanuel 1988) and is much larger than previously observed CAPE values in TC land or oceanic environments at a similar radial distances $r$ from the storm center [i.e., $1500 \mathrm{~J} \mathrm{~kg}^{-1}$ at $r=300 \mathrm{~km}$ over the ocean and $1200 \mathrm{~J} \mathrm{~kg}^{-1}$ over land reported by McCaul (1991) and Bogner et al. (2000), respectively]. The sounding data are also used as input for HID algorithm and to infer the heights of the temperatures in the following discussion.

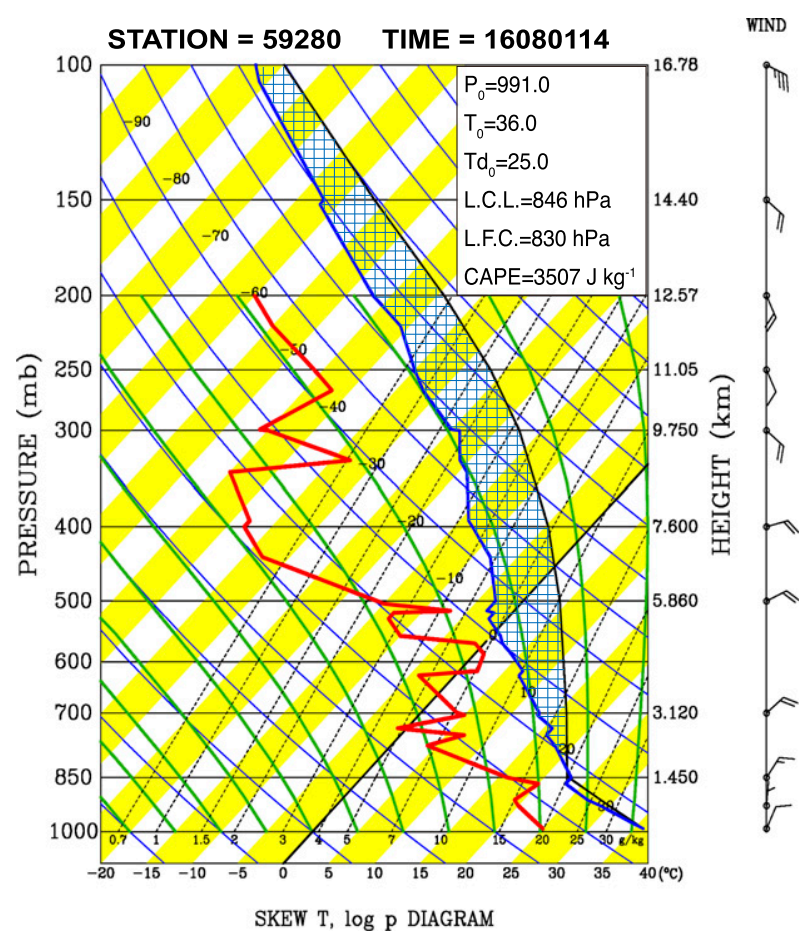

FIG. 2. The skew $T-\log p$ diagram and vertical wind profile of the Qingyuan radiosonde. The blue and red lines are the temperature and dewpoint temperature profiles, respectively.

\section{Results and discussion}

\section{a. Microphysical characteristics of mature convective cells}

The composite $Z_{\mathrm{H}}$ at 3-km altitude of Typhoon Nida at 1000 UTC 1 August is shown in Fig. 1. The outer rainband comprises numerous scattered convective cells. To examine the structures and evolution of these convective cells, they are separated into three groups: developing, mature, and decaying. Following the convective cell identification method used in Moon and Nolan (2015), the classification is based on updraft intensity and temporal variations at $3-\mathrm{km}$ altitude. Therefore, the cells selected for analysis are located in the dual-Doppler analysis domain where the retrieval of vertical velocity is possible. The cells are classified as mature if the updraft speed is $>3 \mathrm{~m} \mathrm{~s}^{-1}$ at $3 \mathrm{~km}$, developing if the updraft speed is $<3 \mathrm{~m} \mathrm{~s}^{-1}$ and has never reached this intensity before, and decaying if the updraft speed decreases below $3 \mathrm{~m} \mathrm{~s}^{-1}$ again. Based on these criteria, there are 111, 164, and 69 samples of developing, mature, and decaying cells, respectively, identified by 31 radar volume scans.

Figure 3 gives an example of a mature convective cell at 1018 UTC 1 August. In Fig. 3a, the black solid contours are upward motion at 3-km altitude, whereas 


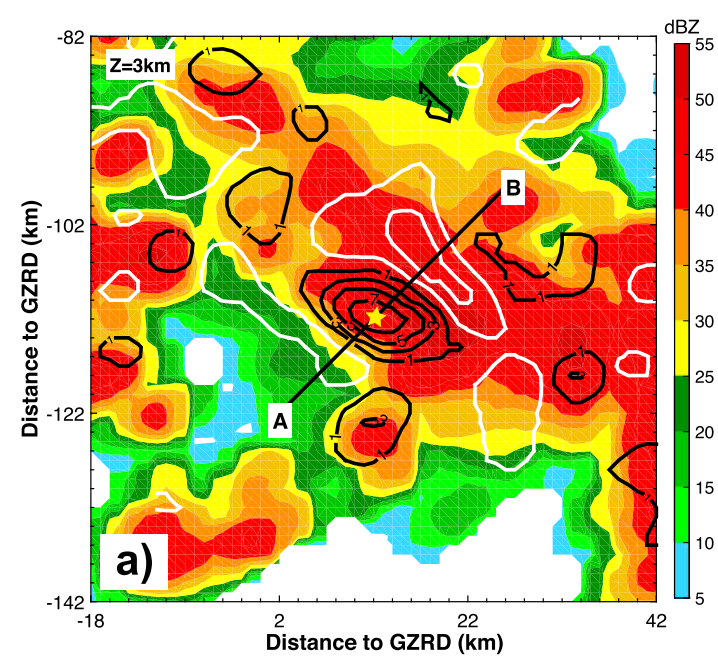

A
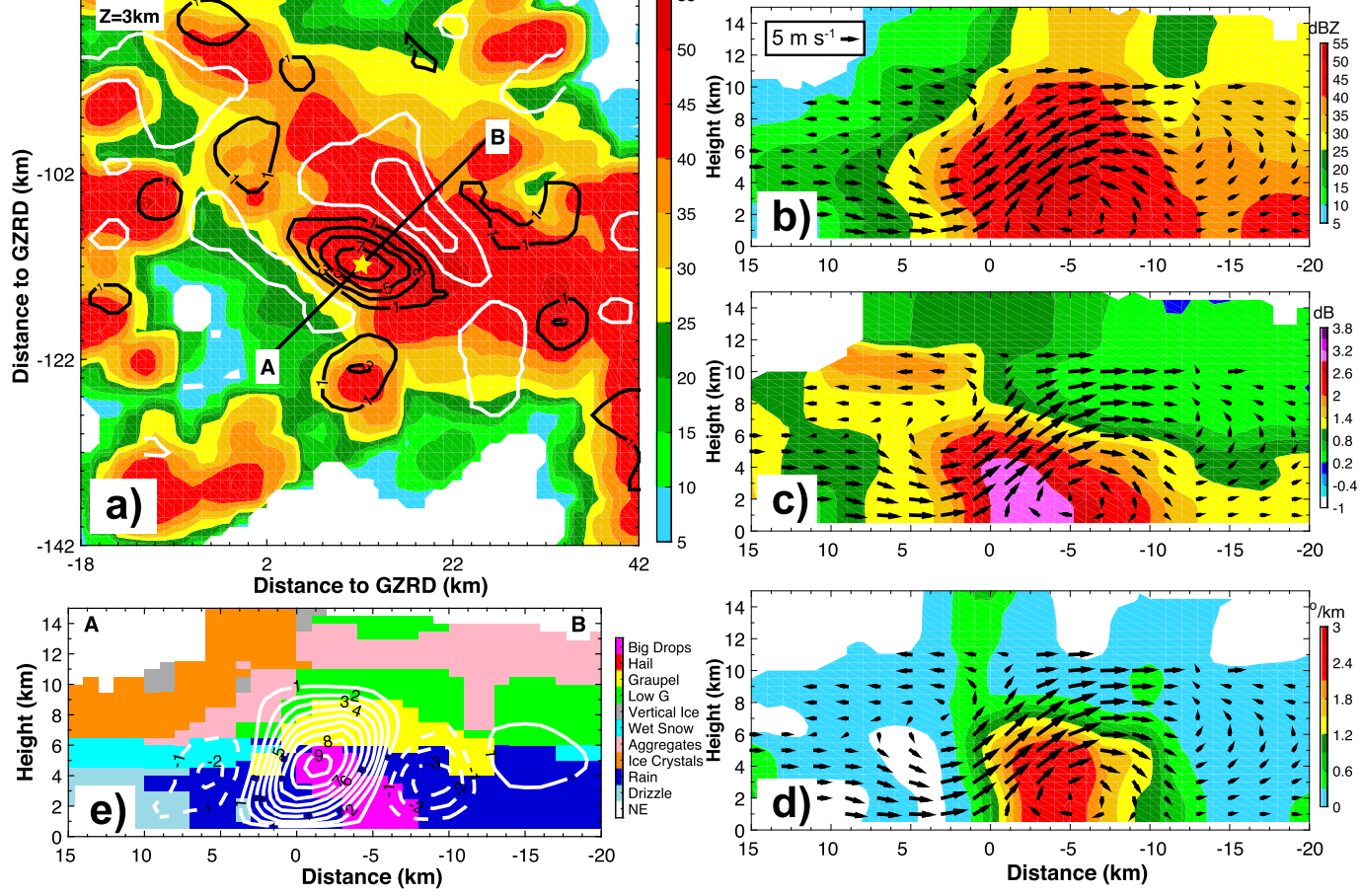

FIG. 3. (a) Equivalent reflectivity factor at horizontal polarization $Z_{\mathrm{H}}$ at $3-\mathrm{km}$ altitude (in $\mathrm{dB} Z$, shaded according to scale) for an example of a convective cell in mature stage at 1018 UTC 1 Aug. The yellow star marks the center of the identified mature convective cell. The black (white) solid contours are upward (downward) motion at $1 \mathrm{~m} \mathrm{~s}^{-1}$ intervals at 3-km altitude. The vertical cross sections of (b) $Z_{\mathrm{H}}\left(\mathrm{dB} Z\right.$, shaded according to scale), (c) $Z_{\mathrm{DR}}(\mathrm{dB})$, and (d) $K_{\mathrm{DP}}\left({ }^{\circ} \mathrm{km}^{-1}\right)$, and (e) hydrometeor types taken along the black line labeled $\mathrm{AB}$ in (a). Line $\mathrm{AB}$ parallels to the direction of the rainband motion. Black vectors indicate the winds in the plane of the cross section in (b), (c), and (d). The updrafts are indicated by solid white contours, and downdrafts are indicated by dashed contours at $1 \mathrm{~m} \mathrm{~s}^{-1}$ intervals in (e). Axis labels for each are in $\mathrm{km}$.

white solid contours are downward motion. The yellow star marks the center of the identified mature convective cell. The cross sections displayed in Figs. 3b-e are taken along the black line $\mathrm{AB}$ parallel to the direction of the rainband motion, and the horizontal wind vectors are rainband-relative winds. As revealed in Fig. 3b, the vertical structure across this mature convective cell is similar to the airflow of the convective region of squall lines (Houze 1989), and consistent with the TC outer rainband convection documented by previous studies (Yu and Tsai 2013; Moon and Nolan 2015). Low-level inflow dominates at the front side of the convection, and it is lifted upward to form a rearward-sloping convective updraft. A relatively weak inflow formed by a branch of downward motion can be found behind the updraft. This inflow is not apparent as the rear-to-front inflow illustrated in $\mathrm{Yu}$ and Tsai (2013), whose cross sections were taken along the arc-shaped echoes that are a signature of a strong downdraft spreading out below a convective cell (Houze 2010).
In Fig. 3c, the maximum $Z_{\mathrm{DR}}$ value near the surface within the convective cell is below the updraft, and is collocated with the maximum in $Z_{\mathrm{H}}$. For liquid particles, larger raindrops become more oblate than smaller ones as a result of deformation by aerodynamic drag. Because $Z_{\mathrm{DR}}$ is a measure of the reflectivity-weighted axis ratio of the particles small compared to the radar wavelength, rainfall characterized by larger mean raindrop size will have larger observed $Z_{\mathrm{DR}}$ values (e.g., Seliga and Bringi 1976; Doviak and Zrnić 1993; Kumjian 2013). In this mature cell, the surface $Z_{\mathrm{DR}}$ maximum is $\sim 3.4 \mathrm{~dB}$, corresponding to a mass-weighted mean diameter $D_{m}$ of $\sim 3.4 \mathrm{~mm}$ based on drop size distribution retrievals (Zhang et al. 2001), indicating the preponderance of large raindrops. Above the $0^{\circ} \mathrm{C}$ level $(\sim 5.3 \mathrm{~km}$ based on the environmental sounding in Fig. 2), there is a positive $Z_{\mathrm{DR}}$ column near the updraft, where $Z_{\mathrm{DR}}$ values $>1.5 \mathrm{~dB}$ extend to $\sim 7.5-\mathrm{km}$ altitude (Fig. $3 \mathrm{c}$ ). A $K_{\mathrm{DP}}$ column is also present, with values $>1.0^{\circ} \mathrm{km}^{-1}$ also extending to $\sim 7.5-\mathrm{km}$ altitude (Fig. $3 \mathrm{~d}$ ). The $Z_{\mathrm{DR}}$ columns and $K_{\mathrm{DP}}$ columns are indicative of supercooled 

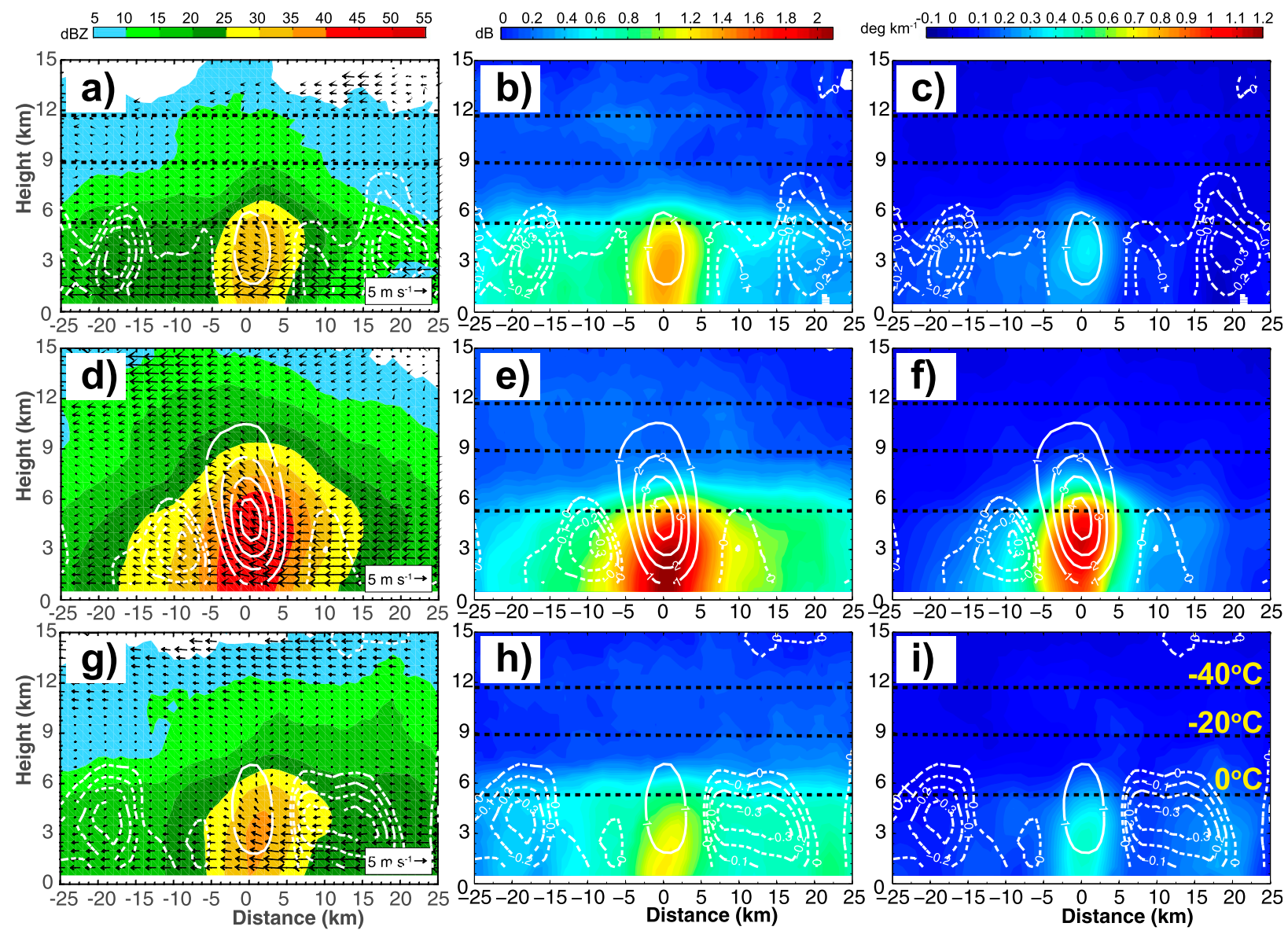

FIG. 4. Composite-mean vertical cross sections of (a),(d),(g) $Z_{\mathrm{H}}$ (in dBZ), (b),(e),(h) $Z_{\mathrm{DR}}$ (in dB), and (c),(f),(i) $K_{\mathrm{DP}}\left(\right.$ in $\left.{ }^{\circ} \mathrm{km}^{-1}\right)$ of the convective cells for (from top to bottom) developing, mature, and decaying along the motion direction of the outer rainband. The white contours represent vertical velocity, with solid lines at $1 \mathrm{~m} \mathrm{~s}^{-1}$ intervals for updraft and dashed lines at $0.1 \mathrm{~m} \mathrm{~s}^{-1}$ intervals for downdraft. Horizontal dashed black lines indicate altitudes corresponding to (from top to bottom) $-40^{\circ},-20^{\circ}$, and $0^{\circ} \mathrm{C}$, respectively.

liquid particles being lifted by the updraft (e.g., Kumjian et al. 2014a).

With the existence of supercooled liquid water associated with a strong updraft, it is likely that the ice particles within the updraft would experience riming, leading to hydrometeors like graupel. The HID algorithm-retrieved particle types shown in Fig. 3e are supportive of this speculation, showing that graupel dominates in the updraft region above the $0^{\circ} \mathrm{C}$ level, with low-density graupel above the high-density graupel. Note that the partitioning of low- and highdensity graupel in such algorithms (e.g., Dolan et al. 2013) should be taken with caution, as it is unlikely that such a distinction can be made from polarimetric radar data alone. Away from the updraft, aggregates are inferred as the most dominant ice particles above the $0^{\circ} \mathrm{C}$ level. Outside the updraft region, a clear melting layer signature and the HID suggest icephased particles begin melting into wet snow near $5.5-\mathrm{km}$ altitude. The particles finally become raindrops beneath the melting layer. The "drizzle" category in the HID algorithm (Dolan et al. 2013) is likely a misidentification of light rain: drizzle implies rain generated via warm-rain processes, whereas this case exhibits clear melting. Aside from these caveats, the HID-retrieved hydrometeor distribution in this example is consistent with the analysis of the polarimetric variables (Figs. 3c,d), thereby providing a physically reasonable result.

\section{b. Evolution of the microphysical characteristics}

To obtain the evolution of the microphysical characteristics of the convective cells in the outer rainband, we will examine the three groups of cells (developing, mature, and decaying) as identified above. Figure 4 shows the composite-mean vertical cross section of $Z_{\mathrm{H}}, Z_{\mathrm{DR}}$, and $K_{\mathrm{DP}}$ of the convective cells along the direction of rainband motion for each of these groups. 
At the developing stage (top row), the composited convective cell $Z_{\mathrm{H}}>30 \mathrm{~dB} Z$ extends to $\sim 5.5-\mathrm{km}$ height, just above the melting level (Fig. 4a). The upward motion in the convective cell is relatively weak with downward motion flanking on both the front and rear sides (Fig. 4a). When the cells develop into their mature stage, the composite kinematic structure resembles the typical structure of mature convective cells with the $30-\mathrm{dB} Z$ contour reaching as high as $9.5 \mathrm{~km}$, including a layer of inflow feeding the convection from the front, a rearward-sloping updraft, and a compensating rearward downdraft (Fig. 4d). In the decaying stage, the 30-dBZ contour descends to about $7 \mathrm{~km}$ as the updraft weakens (Fig. 4g). During the evolution of the convective cell, the surface $Z_{\mathrm{H}}$ maximum is the widest and largest $(\sim 50 \mathrm{~dB} Z)$ in the mature stage, suggesting the strongest surface precipitation in this stage (Fig. $4 \mathrm{~d}$ ).

The evolution of polarimetric variables is shown in the right two columns of Fig. 4. As the convective cell becomes stronger at the mature stage, the maximum values of $Z_{\mathrm{DR}}$ and $K_{\mathrm{DP}}$ near the surface become larger and their widths increase. This also suggests that the mean raindrop size and the total liquid water content in the mature stage are the largest, which relates closely to the strongest surface precipitation. Large $Z_{\mathrm{DR}}$ and $K_{\mathrm{DP}}$ values above the $0^{\circ} \mathrm{C}$ level are also at a higher altitude in the mature stage, indicating the signature of a mature $Z_{\mathrm{DR}}$ and $K_{\mathrm{DP}}$ column on average. This is similar to the composited midlatitude continental convective cells reported in Homeyer and Kumjian (2015).

To quantitatively compare the polarimetric variables at different stages of convective cells, the median vertical profile of each variable in the cell center $(x=0)$ is extracted (Fig. 5). In Fig. 5a, the $Z_{\mathrm{H}}$ median profiles in the updraft show similar patterns above the $0^{\circ} \mathrm{C}$ level in all the three stages: $Z_{\mathrm{H}}$ values increase sharply toward the ground. As in Fig. 4, the mature stage exhibits the largest surface $Z_{\mathrm{H}}$. Beneath the melting layer, the $Z_{\mathrm{H}}$ values are all nearly constant with height in all three stages. This trend indicates that the primary growth of particle sizes and increase in number concentration are above the $0^{\circ} \mathrm{C}$ level. The lack of a clear melting layer "brightband" signature in all the three stages is consistent with profiles from convective precipitation, where rimed ice particles are the dominant hydrometeors contributing to rainfall below. Further, the $Z_{\mathrm{DR}}$ and $K_{\mathrm{DP}}$ profiles are consistent with melting of rimed ice (e.g., Ryzhkov et al. 2013) and a lack of significant growth via warm-rain processes (e.g., Rosenfeld and Ulbrich 2003; Kumjian and Prat 2014). The $K_{\mathrm{DP}}$ maximum just below the melting layer during the mature stage can be mostly attributed to the melting of larger ice hydrometeors (i.e., graupel), which has been documented by a modeling study
(Ryzhkov et al. 2013) and observations (e.g., Cifelli et al. 2002; Rowe et al. 2012). Together, these imply the dominance of ice processes contributing to the heavy rainfall.

Above the $0^{\circ} \mathrm{C}$ level, the particle growth processes are divided into two layers based on the characteristics of the polarimetric profiles (Figs. 5b-d). The first layer is between 12 and $8 \mathrm{~km}$ (corresponding to the temperature regimes below $-14^{\circ} \mathrm{C}$ ), where $Z_{\mathrm{H}}$ increases rapidly while $Z_{\mathrm{DR}}$ decreases slightly. Large aggregates are usually observed to have very low $Z_{\mathrm{DR}}$ because of their low density and the increased fluttering (e.g., Kumjian 2013). Additionally, their large sizes compared to the pristine crystals tend to cause larger $Z_{\mathrm{H}}$ values. Thus, the increasing $Z_{\mathrm{H}}$ and decreasing $Z_{\mathrm{DR}}$ with decreasing height is a good indication of the ongoing aggregation process in this layer.

The second layer is between $8 \mathrm{~km}$ (about $-14^{\circ} \mathrm{C}$ ) and the $0^{\circ} \mathrm{C}$ level, where both the $Z_{\mathrm{H}}$ and $Z_{\mathrm{DR}}$ profiles exhibit a sharp increase toward the $0^{\circ} \mathrm{C}$ level. There is also an increase in the $K_{\mathrm{DP}}$ profiles. In the updraft region, there usually exists a particle freezing zone marked by an enhanced linear depolarization ratio $L_{\mathrm{DR}}$, or decreased $\rho_{\mathrm{HV}}$ and sharply decreased $Z_{\mathrm{DR}}$ relative to the region just below (Kumjian et al. 2012). Although $L_{\mathrm{DR}}$ is not available in this dataset, $\rho_{\mathrm{HV}}$ decreases from 0.98 at $8 \mathrm{~km}$ to 0.96 at $6 \mathrm{~km}$ (not shown). The observed $Z_{\mathrm{DR}}$ behavior and the decrease in $\rho_{\mathrm{HV}}$ might indicate hydrometeor freezing in the updraft during their entire life cycles of convective cells in this outer rainband. Another important feature in the second layer is the more noticeable increase of $Z_{\mathrm{DR}}$ and $K_{\mathrm{DP}}$ in the mature stage, indicating the most robust $Z_{\mathrm{DR}}$ and $K_{\mathrm{DP}}$ columns. Stronger updrafts (Fig. 5d) and subsequently greater amounts of supercooled liquid water as indicated by the stout $Z_{\mathrm{DR}}$ and $K_{\mathrm{DP}}$ columns also suggest more active riming in the mature stage. When riming occurs, $Z_{\mathrm{H}}$ becomes larger as a result of the particle's increased mass, and $Z_{\mathrm{DR}}$ tends to be near zero since most rimed particles are quasi spherical and/or tumbling (e.g., Kumjian 2013; Kumjian et al. 2014a,b). In the second layer, although the median $Z_{\mathrm{DR}}$ and $K_{\mathrm{DP}}$ increase toward the freezing level as a result of the existence of supercooled liquid water, the increase of $Z_{\mathrm{H}}$ reflects the occurrence of riming. The larger increase in $Z_{\mathrm{H}}$ in the mature stage suggests that larger and/or more graupel is produced by the more active riming processes. The fallout of these ice-phased particles is seemingly related to the intense surface precipitation in the mature stage.

\section{c. Ice microphysical process as inferred from the HID retrievals}

Figure 6 shows the frequency and spatial distribution for three types of hydrometeors (ice crystals, aggregates, 

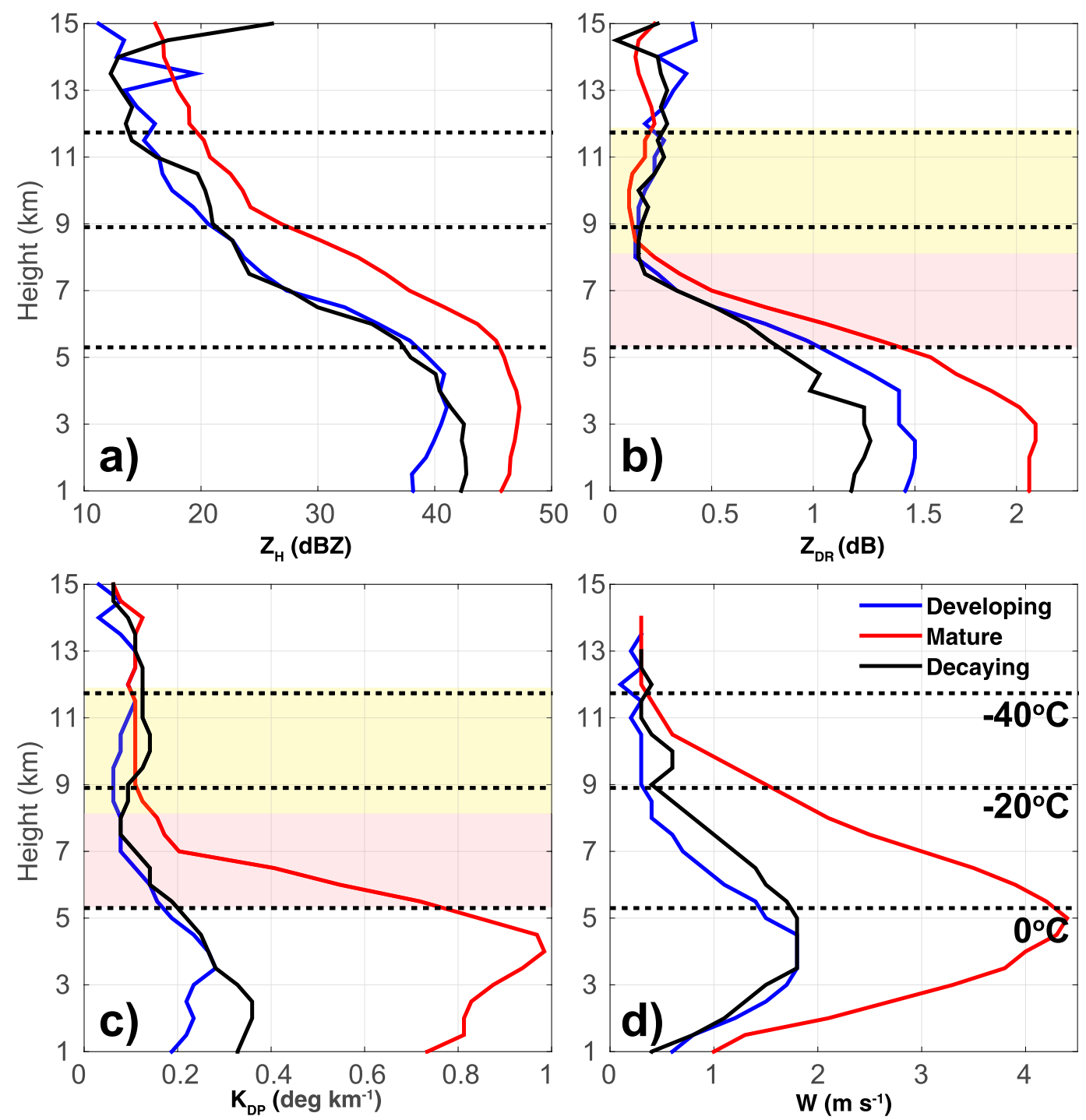

FIG. 5. The vertical profiles of median (a) reflectivity, (b) $Z_{\mathrm{DR}}$, (c) $K_{\mathrm{DP}}$, and (d) vertical velocity at the convective center during three evolution stages. The black dashed lines represent the level of (from top to bottom) $-40^{\circ},-20^{\circ}$, and $0^{\circ} \mathrm{C}$, respectively. The yellow and red shading in (b),(c) denotes the "aggregation zone" and "riming zone," respectively.

and graupel/hail) relative to the location of the updraft at the three different stages of convective cell life cycle identified above. For each point in the updraft-relative cross sections, the frequency that a specific hydrometeor type occurs in individual cross sections is counted and divided by the total sample size at each stage. For example, if 50 out of the 164 cells at the mature stage are identified as graupel at a given point, then the frequency for graupel at that point for mature stage is $\sim 0.3$. If graupel possesses the highest occurrence frequency at a given point compared to the other types of particles, then it is considered the most possible/dominant hydrometeor type, which we then use to infer the most likely microphysical processes. In all three stages, the frequency of the ice crystals is not very high, though they are prevalent everywhere above the melting level except in the strong updraft regions of the mature cases. This is because the presence of any aggregates or graupel in the sampling volume will totally dominate the backscattering properties and thus mask the presence of ice crystals. At the developing stage (Fig. 6d), aggregates are concentrated around the altitude corresponding to $-15^{\circ} \mathrm{C}$, but are found up to altitudes corresponding to the $-20^{\circ} \mathrm{C}$ level at the mature stage. When the convective updraft weakens during the decaying stage, the aggregates again are concentrated near the $-15^{\circ} \mathrm{C}$ level. 

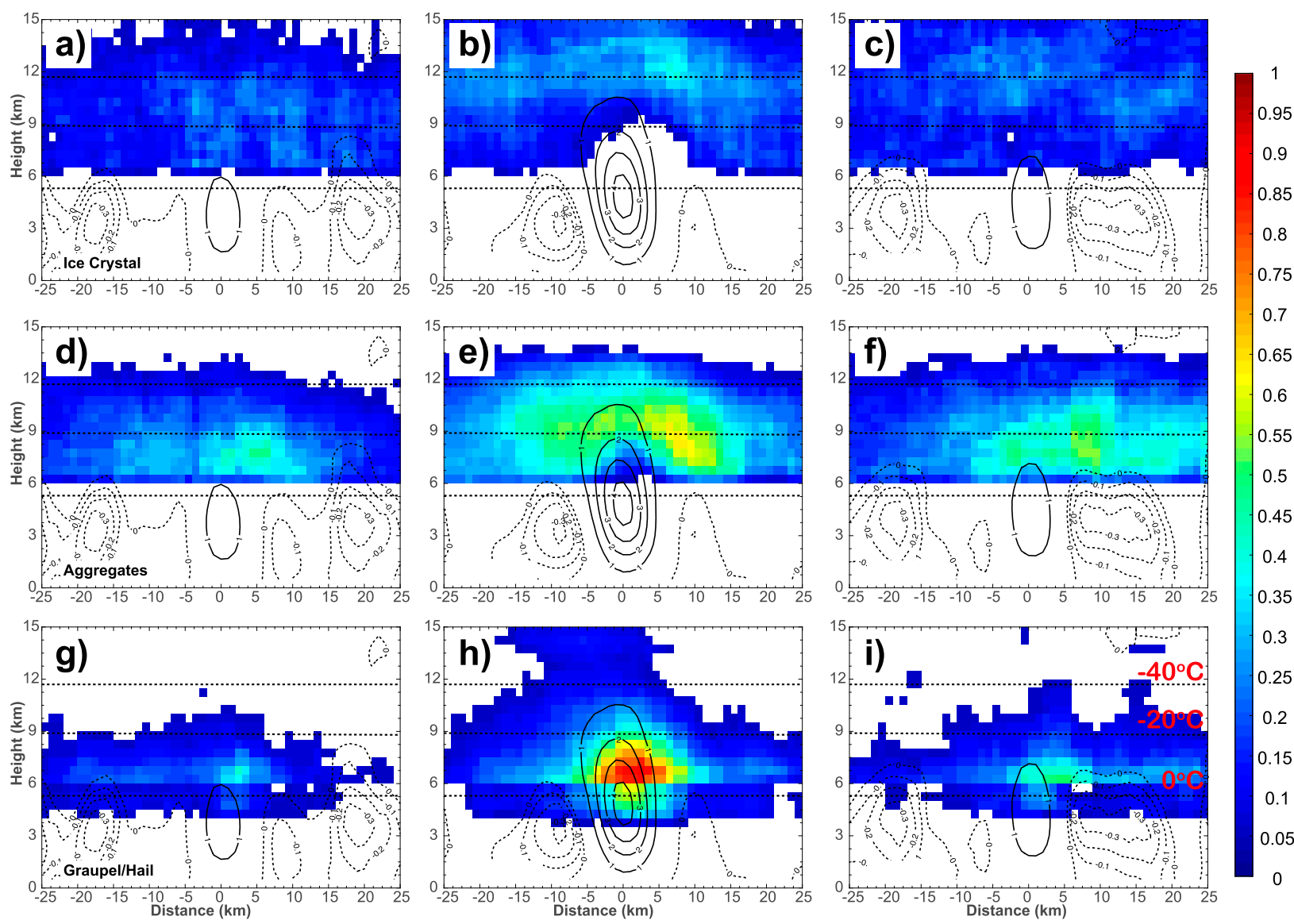

FIG. 6. Composites showing the location of (a)-(c) ice crystal, (d)-(f) aggregates, and (g)-(i) graupel and hail relative to the convective updraft. Shading represents the occurrence frequency of each hydrometeor type at that location. Solid black contours represent vertical velocity, with solid lines at $1 \mathrm{~m} \mathrm{~s}^{-1}$ intervals for updraft and dashed lines at $0.1 \mathrm{~m} \mathrm{~s}^{-1}$ intervals for downdraft. Horizontal black dashed lines indicate altitudes corresponding to (from top to bottom) $-40^{\circ},-20^{\circ}$, and $0^{\circ} \mathrm{C}$, respectively.

Graupel and hail (G/HA) classifications only occur within higher $Z_{\mathrm{H}}$ within the updraft (Figs. $6 \mathrm{~g}-\mathrm{i}$ ) where there is an abundance of supercooled liquid water. The frequency of G/HA is largest at the mature stage when the updraft is the strongest.

Based on the distribution and evolution of the icephased particle inferred from HID, it is suggested that deposition occurs everywhere above the melting level in the convective cells. The pristine ice crystals significantly aggregate at altitude corresponding to $-15^{\circ} \mathrm{C}$ or even higher in mature convective cells. As expected, significant riming only occurs within the convective updraft where particles collect supercooled liquid water. When the convective cells become stronger, larger upward vertical velocities lift more supercooled liquid water to support more active riming that finally produces greater concentrations of rimed particles. The surface precipitation is therefore enhanced as these larger, faster-falling ice particles descend and melt into larger raindrops. This result is consistent with the discussion in sections $3 \mathrm{a}$ and $3 \mathrm{~b}$.

\section{d. Comparison between outer and inner rainband}

The analyses of the vertical profiles of the polarimetric radar variables and the distribution of the HID retrievals indicate that the particle growth in this outer rainband is mainly via ice-phase microphysical processes, which is in sharp contrast to the dominant warmrain processes (collision-coalescence-breakup) below the melting layer in the inner rainband of an inland typhoon (Wang et al. 2016). To evaluate the robustness of this discrepancy between the inner and outer rainbands for landfalling typhoons, we also briefly analyze the microphysical characteristics in an inner rainband of Typhoon Nida (2016), although the microphysics in the inner rainband is not our focus in this study. Different to the discrete convective cell structures in the outer rainband, the inner rainband has a connected band structure 

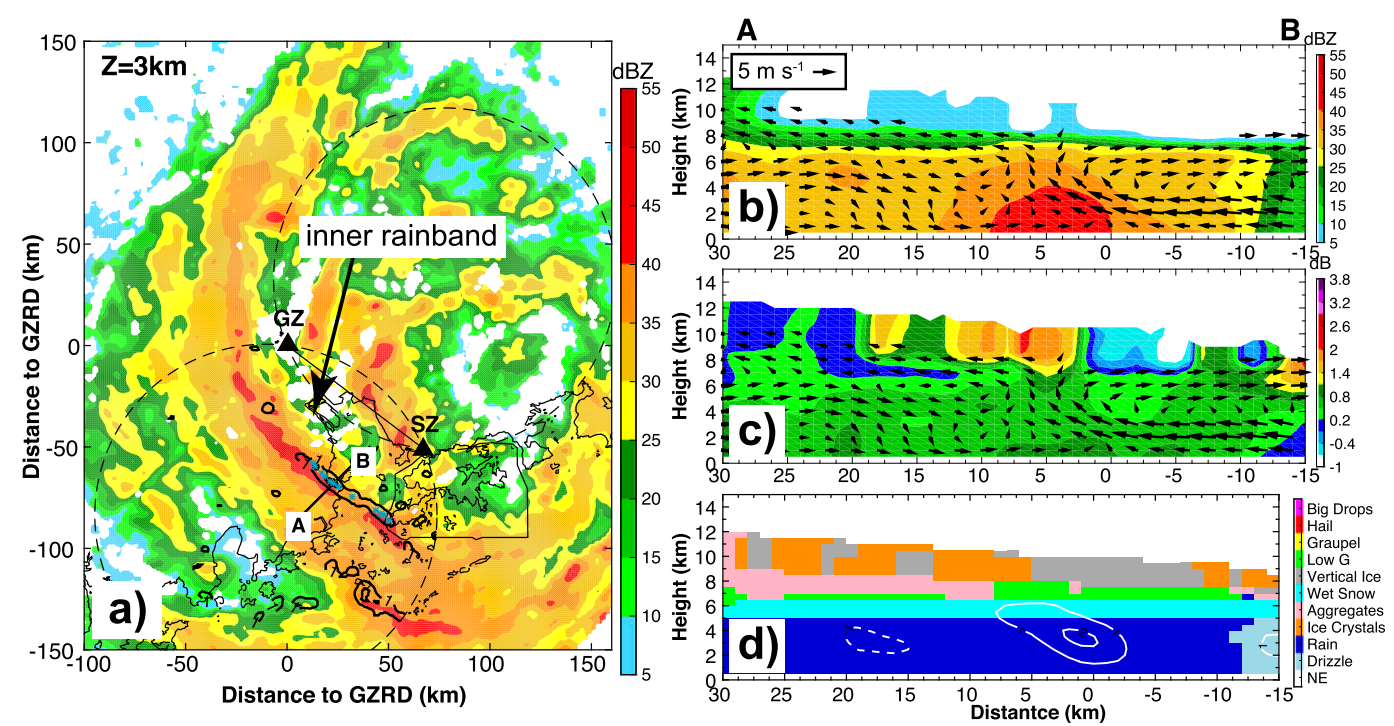

FIG. 7. (a) Horizontal radar reflectivity $Z_{\mathrm{H}}$ at $3-\mathrm{km}$ altitude (dBZ, shading) for an example of the convective region in the inner rainband at 1930 UTC 1 Aug. The black solid contours are upward motion at $1 \mathrm{~m} \mathrm{~s}^{-1}$ intervals at $3-\mathrm{km}$ altitude. The vertical profiles are extracted at the points denoted by the blue asteroids. The vertical cross sections of (b) $Z_{\mathrm{H}}\left(\mathrm{dB} Z\right.$, shading), (c) $Z_{\mathrm{DR}}(\mathrm{dB})$, and (d) hydrometeor types are taken along the black line labeled $\mathrm{AB}$ in (a). Line $\mathrm{AB}$ is normal to this inner rainband. Black vectors indicate the rainband-relative winds in the plane of the cross section in (b) and (c). The updrafts are indicated by solid white contours, and downdrafts are indicated by dashed contours at $1 \mathrm{~m} \mathrm{~s}^{-1}$ intervals in (d). Axis labels for each are in $\mathrm{km}$.

because convective cells are generally azimuthally stretched and smoothed by strong horizontal wind shear of TC circulation in the inner-core region (Fig. 7a). Therefore, we extract 93 points $\left(w>1 \mathrm{~m} \mathrm{~s}^{-1}\right.$ at $\left.3 \mathrm{~km}\right)$ along the convective band from 10 radar sample volume scans during the period from 1900 to 2000 UTC 1 August. We choose the criteria $w>1 \mathrm{~m} \mathrm{~s}^{-1}$ instead of $>3 \mathrm{~m} \mathrm{~s}^{-1}$ in the outer rainband, as we found that the convective updraft in the inner rainband is generally weaker. For example, Figs. 7b-d show an extracted vertical cross section normal to the rainband at 1930 UTC 1 August. This inner rainband is located outside the eyewall at $\sim 100-\mathrm{km}$ radius from the storm center (Fig. 7a). The kinematic structure and microphysics in the inner rainband (Fig. 7) differ substantially from those associated with the outer rainband (Fig. 3). First, the airflow patterns in the inner rainband are similar to those of previously documented typhoon inner rainbands (Barnes et al. 1983; Hence and Houze 2008), but differ fundamentally from the outer rainband that exhibits a squall-line structure. The convective updraft in the inner rainband is relatively weaker than that in the outer rainband (Fig. 3a), and the echo top of the inner rainband only extends to $8-\mathrm{km}$ altitude (Fig. $7 \mathrm{~b}$ ). These kinematic and $Z_{\mathrm{H}}$ structures are consistent with observations from Didlake and Houze (2013a), who found that outer rainbands tended to have deeper and more intense updrafts, and thus taller $Z_{\mathrm{H}}$ towers, than those of inner rainbands. Second, the raindrop sizes in the inner rainband are much smaller, which is suggested by the smaller $Z_{\mathrm{DR}}$ values $(<1.0 \mathrm{~dB}$, see Fig. $7 \mathrm{c})$ and the retrieved mass-weighted mean diameters $D_{m}(<1.5 \mathrm{~mm}$, not shown). Third, the HID algorithm-retrieved particle-type distribution indicates that there are fewer rimed particles above the $0^{\circ} \mathrm{C}$ level (Fig. $7 \mathrm{~d}$ ). The absence of high-density graupel in the convective updraft is consistent with the missing of $Z_{\mathrm{DR}}$ column above the $0^{\circ} \mathrm{C}$ level (Fig. 7c). This is most likely due to the relatively weaker convective updrafts in the inner rainband (e.g., Figs. 7b) that cannot loft sufficient supercooled liquid water above the melting layer, a key factor for the formation of graupel.

The vertical profiles of median $Z_{\mathrm{H}}, Z_{\mathrm{DR}}, K_{\mathrm{DP}}$, and vertical velocity for 93 points in the inner rainband are further calculated and compared with the results at the mature stage of convective cells in the outer rainband (Figs. 8a-d). Consistent with the findings based on the comparison of a single vertical slice, the median intensity of the updraft is much weaker in the inner rainband (Fig. 8d), and the vertical extent of scatters in the inner rainband $\left(Z_{\mathrm{H}}\right.$ profile reaches $\left.\sim 11 \mathrm{~km}\right)$ is much lower than that of the outer rainband $(>15 \mathrm{~km})$. Above the $0^{\circ} \mathrm{C}$ level, the values of $Z_{\mathrm{DR}}$ and $K_{\mathrm{DP}}$ in the inner rainband show very little change (Figs. $8 \mathrm{~b}, \mathrm{c}$ ), while a rapid increase in $Z_{\mathrm{DR}}$ and $K_{\mathrm{DP}}$ with decreasing altitude is found in the outer rainband (Figs. 5b,c). This sharp 

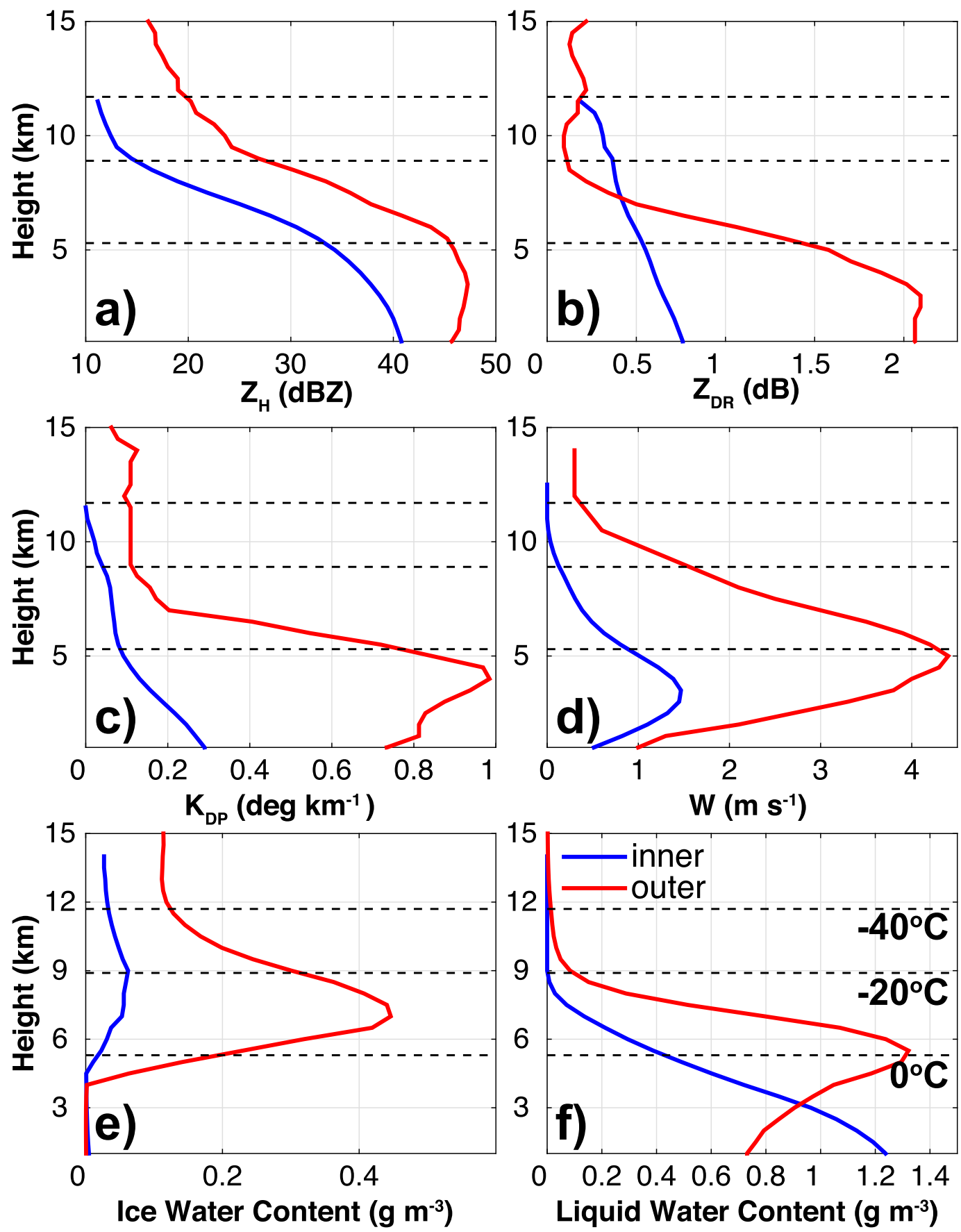

FIG. 8. The median profiles of (a) reflectivity, (b) $Z_{\mathrm{DR}}$, (c) $K_{\mathrm{DP}}$, (d) vertical velocity, (e) ice water content, and (f) liquid water content at the convective center in the inner rainband (blue lines) and the mature stage of the outer rainband (red lines). The black dashed lines represent the level of (from top to bottom) $-40^{\circ},-20^{\circ}$, and $0^{\circ} \mathrm{C}$ for the outer rainband environment, respectively.

contrast suggests that active riming can be only found in the outer rainband. Below the $0^{\circ} \mathrm{C}$ level, the vertical profiles of median polarimetric variables in the inner rainband are similar to those shown by Wang et al. (2016). The simultaneous increase of $Z_{\mathrm{H}}, Z_{\mathrm{DR}}$, and $K_{\mathrm{DP}}$ toward the ground in the inner rainband indicates the high efficiency of warm-rain processes (i.e., raindrop collision-coalescence and/or the collection of cloud water by raindrops). To roughly estimate the relative contribution of ice and warm-rain processes to the 
low-level heavy rainfall, the liquid and ice water contents are calculated based on GZRD observations (Fig. 8e,f), using the same method in Wang et al. (2016). The vertical profiles of the ice and liquid water content of the inner rainband (blue lines in Figs. 8e,f) show a similar pattern as Wang et al. (2016). The liquid water content increases rapid below the melting level, and has an order of magnitude larger than the ice water content. In the contrast, the ice water content in the outer rainband (red lines) is much larger than that in the inner rainband and is comparable to the liquid water content on the surface, suggesting ice rain process playing a more dominant role in Nida's outer rainband.

The above analyses are consistent with previous studies showing that the updrafts in outer rainbands tend to be deeper and stronger than those of inner rainbands. As a result, the dominant microphysical processes leading to surface or low-level rainfall in the outer rainband are indeed distinct from that in the inner rainband as confirmed here. Although the warm-rain processes are dominant in the inner rainband, the ice-phase microphysical processes are more important in the outer rainband.

\section{Summary and conclusions}

In this study, we examined the microphysical characteristics of the convective cells in an outer rainband of Typhoon Nida based on observations collected by the polarimetric radar located at Guangzhou, China. The convective cells in the outer rainband are separated into three stages according to their life cycle. The main conclusions of this study are summarized as follows.

Composite vertical structures of convective cells at different stages indicate that the strongest convective updraft at the mature stage exhibits a rearward slope, similar to the observed kinematic structure in previous studies. The vertical profiles of the polarimetric variables suggest that the major pathway to rainfall is via icephased microphysical processes above the melting level, including aggregation and riming.

This hypothesis is confirmed by the occurrence frequency of different hydrometeors relative to convective updraft retrieved by the HID algorithm (Dolan et al. 2013), which can be used to infer the potential ongoing microphysical processes that occurred in the convective cells. Results show the layered pattern of inferred ice processes. Depositional growth occurs everywhere above the melting level in the convective cells, whereas aggregation is the most prevalent ice-phased process that takes place at the $-15^{\circ} \mathrm{C}$ level or even higher in the stronger updraft of mature convective cells. Riming occurs within the convective updraft in all three stages. In particular, riming tends to happen more frequently in the mature convective cells, and it is a major microphysics contributor to the intense surface precipitation and larger raindrops found in the outer rainband.

The inferred microphysics occurring in this outer rainband is quite different from that of the inner rainband analyzed by Wang et al. (2016). Whereas Wang et al. (2016) found the dominance of warm-rain processes in the inner rainband, here in the outer rainband particle growth is dominated by ice-phased processes. Note that active riming in the outer rainband is similar to that found in a subtropical squall line (Wen et al. 2017). This could be understood given their similar prestorm thermodynamic conditions, as the sounding profiles in these two situations indicates a comparable large CAPE value (3428.3 $\mathrm{J} \mathrm{kg}^{-1}$ in Wen et al. 2017), suggesting the potential for intense updrafts more conductive to active riming.

Finally, one caveat of this study is that the microphysical characteristics of the outer rainband presented herein are drawn from a single case study, and particularly, the outer rainband was entirely over land rather than in a typical oceanic environment. The localized land effect (including complex terrain) may play a role in the kinematic and microphysical structures of convective cells in the outer rainband. Therefore, the conclusions in this study should not be overgeneralized to oceanic TC outer rainbands. To better understand the microphysical processes of TC outer rainbands in different environments, more systematic observational examinations and/or high-resolution numerical simulation analysis are expected in the future.

Acknowledgments. This work was primarily supported by the National Key Research and Development Program of China under Grants 2017YFC1501703, Key Program for International S\&T Cooperation Projects of China (Grant 2017YFE0107700), the National Natural Science Foundation of China (Grants 41705036, 41605033, 41322032, 41475015, 41775064, 41475060, and 41275031), the National Fundamental Research 973 Program of China (2013CB430101 and 2015CB452800), the Open Research Program of the State Key Laboratory of Severe Weather, the Program for New Century Excellent Talents in Universities of China (NCET-13-0287), and the Fundamental Research Funds for the Central Universities. We would also like to acknowledge the China Meteorological Administration and Guangdong Meteorological Service for collecting and archiving the radar data used in this study. Data used in this work are from the National Fundamental Research 973 Program of China (2013CB430101).

\section{REFERENCES}

Akter, N., and K. Tsuboki, 2012: Numerical simulation of Cyclone Sidr using a cloud-resolving model: Characteristics and formation process of an outer rainband. Mon. Wea. Rev., 140, 789-810, https://doi.org/10.1175/2011MWR3643.1. 
Barnes, G. M., and G. J. Stossmeister, 1986: The structure and decay of a rainband in Hurricane Irene (1981). Mon. Wea. Rev., 114, 2590-2601, https://doi.org/10.1175/1520-0493(1986) 114<2590:TSADOA >2.0.CO;2.

_ and convective structure of a hurricane rainband. J. Atmos. Sci., 40, 2125-2137, https://doi.org/10.1175/1520-0469(1983) $040<2125$ :MACSOA $>2.0$. CO;2.

Black, R. A., 1990: Radar reflectivity-ice water content relationships for use above the melting level in hurricanes. J. Appl. Meteor., 29, 955-961, https://doi.org/10.1175/1520-0450(1990) 029<0955:RRIWCR > 2.0.CO;2.

hurricanes. J. Atmos. Sci., 43, 802-822, https://doi.org/10.1175/ 1520-0469(1986)043<0802:OOTDOI>2.0.CO;2.

- , and - 1999: Electrification of the hurricane. J. Atmos. Sci., 56, 2004-2028, https://doi.org/10.1175/1520-0469(1999) 056<2004:EOTH > 2.0.CO;2.

— vertical motions in a Caribbean hurricane. Mon. Wea. Rev., 122, 2722-2739, https://doi.org/10.1175/1520-0493(1994) $122<2722$ :USVMIA $>2.0 . \mathrm{CO} ; 2$.

Bluestein, H. B., and M. H. Jain, 1985: Formation of mesoscale lines of precipitation: Severe squall lines in Oklahoma during the spring. J. Atmos. Sci., 42, 17111732, https://doi.org/10.1175/1520-0469(1985)042<1711: FOMLOP $>2.0 . C O ; 2$.

Bogner, P. B., G. M. Barnes, and J. L. Franklin, 2000: Conditional instability and shear for six hurricanes over the Atlantic Ocean. Wea. Forecasting, 15, 192-207, https://doi.org/10.1175/ 1520-0434(2000)015<0192:CIASFS $>2.0$.CO;2.

Cifelli, R., W. A. Petersen, L. D. Carey, S. A. Rutledge, and M. A. F. Silva Dias, 2002: Radar observations of the kinematic, microphysical, and precipitation characteristics of two MCSs in TRMM LBA. J. Geophys. Res., 107, 8077, https://doi.org/ 10.1029/2000JD000264.

Didlake, A. C., Jr., and R. A. Houze Jr., 2013a: Convective-scale variations in the inner-core rainbands of a tropical cyclone. J. Atmos. Sci., 70, 504-523, https://doi.org/10.1175/JAS-D-120134.1.

— , and 2013b: Dynamics of the stratiform sector of a tropical cyclone rainband. J. Atmos. Sci., 70, 1891-1911, https://doi.org/10.1175/JAS-D-12-0245.1.

— observations of bulk microphysical structures and their relation to vortex kinematics in Hurricane Arthur (2014). Mon. Wea. Rev., 145, 4521-4541, https://doi.org/10.1175/ MWR-D-17-0035.1.

Dolan, B., S. A. Rutledge, S. Lim, V. Chandrasekar, and M. Thurai, 2013: A robust C-band hydrometeor identification algorithm and application to a long-term polarimetric radar dataset. J. Appl. Meteor. Climatol., 52, 2162-2186, https://doi.org/ 10.1175/JAMC-D-12-0275.1.

Doviak, R. J., and D. S. Zrnić, 1993: Doppler Radar \& Weather Observations. 2nd ed. Academic Press, 562 pp.

Fang, J., and F. Zhang, 2012: Effect of beta shear on simulated tropical cyclones. Mon. Wea. Rev., 140, 3327-3346, https:// doi.org/10.1175/MWR-D-10-05021.1.

Fovell, R. G., and H. Su, 2007: Impact of cloud microphysics on hurricane track forecasts. Geophys. Res. Lett., 34, 497-507, https://doi.org/10.1029/2007GL031723.

— , K. L. Corbosiero, and H.-C. Kuo, 2009: Cloud microphysics impact on hurricane track as revealed in idealized experiments. J. Atmos. Sci., 66, 1764-1778, https://doi.org/ 10.1175/2008JAS2874.1.

Hence, D. A., and R. A. Houze Jr., 2008: Kinematic structure of convective-scale elements in the rainbands of Hurricanes Katrina and Rita (2005). J. Geophys. Res., 113, 596-598, https://doi.org/10.1029/2007JD009429.

Homeyer, C. R., and M. R. Kumjian, 2015: Microphysical characteristics of overshooting convection from polarimetric radar observations. J. Atmos. Sci., 72, 870-891, https://doi.org/ 10.1175/JAS-D-13-0388.1.

Houze, R. A., Jr., 1989: Observed structure of mesoscale convective systems and implications for large-scale heating. Quart. J. Roy. Meteor. Soc., 115, 425-461, https://doi.org/10.1002/ qj. 49711548702 .

_ 2010: Clouds in tropical cyclones. Mon. Wea. Rev., 138, 293 344, https://doi.org/10.1175/2009MWR2989.1.

Huang, H., G. Zhang, K. Zhao, and S. E. Giangrande, 2017: A hybrid method to estimate specific differential phase and rainfall with linear programming and physics constraints. IEEE Trans. Geosci. Remote Sens., 55, 96-111, https://doi.org/ 10.1109/TGRS.2016.2596295.

Hubbert, J. C., S. M. Ellis, W.-Y. Chang, S. Rutledge, and M. Dixon, 2014: Modeling and interpretation of S-band ice crystal depolarization signatures from data obtained by simultaneously transmitting horizontally and vertically polarized fields. J. Appl. Meteor. Climatol., 53, 1659-1677, https:// doi.org/10.1175/JAMC-D-13-0158.1.

Kumjian, M. R., 2013: Principles and applications of dualpolarization weather radar. Part I: Description of the polarimetric radar variables. J. Oper. Meteor., 1, 226-242, https:// doi.org/10.15191/nwajom.2013.0119.

—_, and O. P. Prat, 2014: The impact of raindrop collisional processes on the polarimetric radar variables. J. Atmos. Sci., 71, 3052-3067, https://doi.org/10.1175/ JAS-D-13-0357.1.

— S. M. Ganson, and A. V. Ryzhkov, 2012: Freezing of raindrops in deep convective updrafts: A microphysical and polarimetric model. J. Atmos. Sci., 69, 3471-3490, https://doi.org/ 10.1175/JAS-D-12-067.1.

_ A. P. Khain, N. Benmoshe, E. Ilotoviz, A. V. Ryzhkov, and V. T. J. Phillips, 2014a: The anatomy and physics of $Z_{D R}$ columns: Investigating a polarimetric radar signature with a spectral bin microphysical model. J. Appl. Meteor. Climatol., 53, 1820-1843, https://doi.org/10.1175/JAMC-D-13-0354.1.

— S. A. Rutledge, R. M. Rasmussen, P. C. Kennedy, and M. Dixon, 2014b: High-resolution polarimetric radar observations of snow-generating cells. J. Appl. Meteor. Climatol., 53, 1636-1658, https://doi.org/10.1175/JAMC-D-13-0312.1.

Marks, F. D., Jr., and R. A. Houze Jr., 1987: Inner core structure of Hurricane Alicia from airborne Doppler radar observations. J. Atmos. Sci., 44, 1296-1317, https://doi.org/10.1175/ 1520-0469(1987)044<1296:ICSOHA>2.0.CO;2.

May, P. T., J. D. Kepert, and T. D. Keenan, 2008: Polarimetric radar observations of the persistently asymmetric structure of Tropical Cyclone Ingrid. Mon. Wea. Rev., 136, 616-630, https://doi.org/10.1175/2007MWR2077.1.

McCaul, E. W., 1991: Buoyancy and shear characteristics of hurricane-tornado environments. Mon. Wea. Rev., 119, 1954-1978, https://doi.org/10.1175/1520-0493(1991)119<1954: $\mathrm{BASCOH}>2.0 . \mathrm{CO} ; 2$.

McFarquhar, G. M., H. Zhang, G. Heymsfield, J. B. Halverson, R. Hood, J. Dudhia, and F. Marks Jr., 2006: Factors affecting the evolution of Hurricane Erin (2001) and the distributions 
of hydrometeors: Role of microphysical processes. J. Atmos. Sci., 63, 127-150, https://doi.org/10.1175/JAS3590.1.

Moon, Y., and D. S. Nolan, 2015: Spiral rainbands in a numerical simulation of Hurricane Bill (2009). Part I: Structures and comparisons to observations. J. Atmos. Sci., 72, 164-190, https://doi.org/10.1175/JAS-D-14-0058.1.

Oye, R., C. Mueller, and S. Smith, 1995: Software for radar translation, visualization, editing, and interpolation. Preprints, 27th Conf. on Radar Meteorology, Vail, CO, Amer. Meteor. Soc., 359-361.

Powell, M. D., 1990a: Boundary layer structure and dynamics in outer hurricane rainbands. Part I: Mesoscale rainfall and kinematic structure. Mon. Wea. Rev., 118, 891-917, https:// doi.org/10.1175/1520-0493(1990)118<0891:BLSADI >2.0.CO;2. , 1990b: Boundary layer structure and dynamics in outer hurricane rainbands. Part II: Downdraft modification and mixed layer recovery. Mon. Wea. Rev., 118, 918-938, https://doi.org/ 10.1175/1520-0493(1990)118<0918:BLSADI > 2.0.CO;2.

Ray, P. S., K. K. Wagner, K. W. Johnson, J. J. Stephens, W. C. Bumgarner, and E. A. Mueller, 1978: Triple-Doppler observations of a convective storm. J. Appl. Meteor., 17, 1201-1212, https://doi.org/10.1175/1520-0450(1978)017<1201: TDOOAC $>2.0 . \mathrm{CO} ; 2$.

Rosenfeld, D., and C. W. Ulbrich, 2003: Cloud microphysical properties, processes, and rainfall estimation opportunities. Radar and Atmospheric Science: A Collection of Essays in Honor of David Atlas, Meteor. Monogr., No. 52, Amer. Meteor. Soc., 237-258, https://doi.org/10.1175/0065-9401(2003) $030<0237$ :CMPPAR $>2.0 . \mathrm{CO} ; 2$.

Rowe, A. K., and R. A. Houze Jr., 2014: Microphysical characteristics of MJO convection over the Indian Ocean during DYNAMO. J. Geophys. Res. Atmos., 119, 2543-2554, https:// doi.org/10.1002/2013JD020799.

— S. A. Rutledge, and T. J. Lang, 2012: Investigation of microphysical processes occurring in organized convection during NAME. Mon. Wea. Rev., 140, 2168-2187, https://doi.org/ 10.1175/MWR-D-11-00124.1.

Rozoff, C. M., D. S. Nolan, J. P. Kossin, F. Zhang, and J. Fang, 2012: The roles of an expanding wind field and inertial stability in tropical cyclone secondary eyewall formation. J. Atmos. Sci., 69, 2621-2643, https://doi.org/10.1175/JAS-D-11-0326.1.

Ryzhkov, A. V., and D. S. Zrnić, 2007: Depolarization in ice crystals and its effect on radar polarimetric measurements. J. Atmos. Oceanic Technol., 24, 1256-1267, https://doi.org/ 10.1175/JTECH2034.1.

_, M. R. Kumjian, S. M. Ganson, and A. P. Khain, 2013: Polarimetric radar characteristics of melting hail. Part I: Theoretical simulations using spectral microphysical modeling. J. Appl. Meteor. Climatol., 52, 2849-2870, https://doi.org/ 10.1175/JAMC-D-13-073.1.

Seliga, T. A., and V. N. Bringi, 1976: Potential use of radar differential reflectivity measurements at orthogonal polarizations for measuring precipitation. J. Appl. Meteor., 15, 69-76, https://doi.org/10.1175/1520-0450(1976)015<0069: PUORDR $>2.0 . \mathrm{CO} ; 2$.
Senn, H. V., and H. W. Hiser, 1959: On the origin of hurricane spiral rain bands. J. Meteor., 16, 419-426, https://doi.org/ 10.1175/1520-0469(1959)016<0419:OTOOHS >2.0.CO;2.

Skwira, G. D., J. L. Schroeder, and R. E. Peterson, 2005: Surface observations of landfalling hurricane rainbands. Mon. Wea. Rev., 133, 454-465, https://doi.org/10.1175/MWR-2866.1.

Sun, Y. Q., Y. Jiang, B. Tan, and F. Zhang, 2013: The governing dynamics of the secondary eyewall formation of Typhoon Sinlaku (2008). J. Atmos. Sci., 70, 3818-3837, https://doi.org/ 10.1175/JAS-D-13-044.1.

Wang, M., K. Zhao, M. Xue, G. Zhang, S. Liu, L. Wen, and G. Chen, 2016: Precipitation microphysics characteristics of a Typhoon Matmo (2014) rainband after landfall over eastern China based on polarimetric radar observations. J. Geophys. Res. Atmos., 121, 12 415-12 433, https://doi.org/ 10.1002/2016JD025307.

Wang, Y., 2002: Vortex Rossby waves in a numerically simulated tropical cyclone. Part II: The role in tropical cyclone structure and intensity changes. J. Atmos. Sci., 59, 1239-1262, https://doi.org/ 10.1175/1520-0469(2002)059<1239:VRWIAN > 2.0.CO;2.

, 2009: How do outer spiral rainbands affect tropical cyclone structure and intensity? J. Atmos. Sci., 66, 1250-1273, https:// doi.org/10.1175/2008JAS2737.1.

Wen, J., and Coauthors, 2017: Evolution of microphysical structure of a subtropical squall line observed by a polarimetric radar and a disdrometer during OPACC in eastern China. J. Geophys. Res. Atmos., 122, 8033-8050, https://doi.org/ 10.1002/2016JD026346.

Wexler, H., 1947: Structure of hurricanes as determined by radar. Ann. N.Y. Acad. Sci., 48, 821-845, https://doi.org/10.1111/ j.1749-6632.1947.tb38495.x.

Willoughby, H. E., 1990: Temporal changes of the primary circulation in tropical cyclones. J. Atmos. Sci., 47, 242-264, https://doi.org/ 10.1175/1520-0469(1990)047<0242:TCOTPC > 2.0.CO;2.

, F. D. Marks Jr., and R. J. Feinberg, 1984: Stationary and moving convective bands in hurricanes. J. Atmos. Sci., 41, 3189-3211, https://doi.org/10.1175/1520-0469(1984)041<3189: SAMCBI $>2.0 . \mathrm{CO} ; 2$.

Wyss, J., and K. A. Emanuel, 1988: The pre-storm environment of midlatitude prefrontal squall lines. Mon. Wea. Rev., 116, 790-794, https://doi.org/10.1175/1520-0493(1988)116<0790: TPSEOM $>2.0 . \mathrm{CO} ; 2$.

Yu, C.-K., and C.-L. Tsai, 2013: Structural and surface features of arc-shaped radar echoes along an outer tropical cyclone rainband. J. Atmos. Sci., 70, 56-72, https://doi.org/10.1175/ JAS-D-12-090.1.

Zhang, F., D. Tao, Y. Q. Sun, and J. D. Kepert, 2017: Dynamics and predictability of secondary eyewall formation in sheared tropical cyclones. J. Adv. Model. Earth Syst., 9, 89-112, https:// doi.org/10.1002/2016MS000729.

Zhang, G., J. Vivekanandan, and E. Brandes, 2001: A method for estimating rain rate and drop size distribution from polarimetric radar measurements. IEEE Trans. Geosci. Remote Sens., 39, 830-841, https://doi.org/10.1109/36.917906. 